\title{
MiRNAs Mediate GDNF-Induced Proliferation and Migration of Glioma Cells
}

\author{
Bao-Le Zhanga Fu-Lu Dong ${ }^{\text {a }}$ Ting-Wen Guo Xiao-He Gua Lin-Yan Huang ${ }^{a}$ \\ Dian-Shuai Gao ${ }^{a}$ \\ aDepartment of Neurobiology and Anatomy, Xuzhou Key Laboratory of Neurobiology, Jiangsu Key \\ Laboratory of New Drug Research and Clinical Pharmacy, Xuzhou Medical University, Xuzhou, Jiangsu, \\ bLaboratory of Nuclear Receptors and Cancer Research, Center for Basic Medical Research, Nantong \\ University School of Medicine, Nantong, Jiangsu, China
}

\section{Key Words}

Glioma $\cdot$ Proliferation and migration $•$ GDNF • MiRNA • Microarray

\begin{abstract}
Background/Aims: Glial cell line-derived neurotrophic factor (GDNF) is an important factor promoting invasive glioma growth. This study was performed to reveal a unique mechanism of glioma cell proliferation and migration. Methods: Human U251 glioma cells were used to screen the optimal GDNF concentration and treatment time to stimulate proliferation and migration. MicroRNA (MiRNA) expression profiles were detected by microarray and confirmed by real-time polymerase chain reaction (PCR). The target genes of differentially expressed miRNAs were predicted by miRWalk, and those targeted by multiple miRNAs were screened with Gene Ontology (GO) and Kyoto Encyclopedia of Genes and Genomes (KEGG) pathway analyses. A regulatory miRNA network was constructed using ingenuity pathway analysis (IPA). Target gene expression of differentially expressed miRNAs was examined by real-time PCR or mRNA microarray. Results: The results show that $50 \mathrm{ng} / \mathrm{mL}$ GDNF for 24 h significantly promotes U251 glioma cell proliferation and migration $(P<0.05)$. Seven miRNAs (hsa-miR194-5p, hsa-miR-152-3p, hsa-miR-205-5p, hsa-miR-629-5p, hsa-miR-3609, hsa-miR-183$5 p$, and hsa-miR-487b-3p) were significantly up-regulated after GDNF treatment $(P<0.05)$. These miRNAs are primarily involved in signal transduction, cell adhesion and cell cycle through mitogen-activated protein kinase (MAPK) signaling, focal adhesion and glioma signal pathways. Five of these miRNAs (hsa-miR-194-5p, hsa-miR-152-3p, hsa-miR-205-5p, hsamiR-183-5p, and hsa-miR-487b-3p) co-regulate TP53 and Akt. mRNA expression levels of four genes co-targeted by two or more up-regulated miRNAs were significantly decreased after GDNF treatment $(P<0.05)$. Conclusion: GDNF treatment of U251 glioma cells significantly increased the expression of seven miRNAs involved in cell adhesion and the cell cycle.
\end{abstract}




\section{Cellular Physiology Cell Physiol Biochem 2017;44:1923-1938

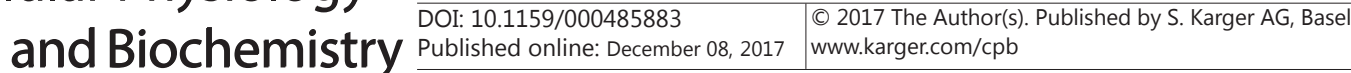 \\ Zhang et al.: miRNAs Regulate GDNF-Promoting Glioma Progression}

\section{Introduction}

Glioma is the most common malignant primary adult human brain tumor and has one of the lowest survival rates of all cancers [1]. Due to its migratory ability and invasive growth characteristics [2], disease prognosis remains poor despite advances in neurosurgery, neuroimaging and related technologies. Recent studies have shown that glioma occurrence and development are associated with abnormal expression of many cytokines including glial cell line-derived neurotrophic factor (GDNF) [3-5]. GDNF is a member of the transforming growth factor beta (TGF- $\beta$ ) super-family that was first isolated and purified in 1993 [6]. GDNF can prolong dopaminergic neuron survival, thus nourishing and protecting populations of peripheral and central neurons including sympathetic, sensory, and motor neurons [7-9]. GDNF was previously considered as an important pro-differentiation factor with specific physiological roles in development and survival. This hypothesis was challenged by Wiesenhofer and colleagues, who reported abnormally high GDNF expression in primary glioma tissues and multiple glioma cell lines. Notably, the increase positively correlated with pathological tumor grade [10]. Subsequent research revealed that GDNF strongly induces glioma cell proliferation and migration [11-13]. Knocking down expression of GDNF or its receptor GDNF family receptor $\alpha 1$ (GFR $\alpha 1$ ) effectively inhibits the pathological progression of glioma $[14,15]$. GDNF mainly exerts its functions via the GFR $\alpha 1 /$ Ret receptor complex [16]. We previously demonstrated that integrin $\beta 1$, neural cadherin ( $N$-cadherin), and neural cell adhesion molecule (NCAM) adhesion molecules on the cell membrane can act as the signal transduction receptors of GDNF to activate phosphoinositide 3-kinase/protein kinase $\mathrm{B}$ (PI3K/Akt) and mitogen-activated protein kinase (MAPK) signaling [17-20]. Others have shown that downstream factors in these signaling pathways, such as Ki-67, proliferating cell nuclear antigen (PCNA), matrix metalloproteinase 13 (MMP13), and RhoA, significantly promote glioma cell proliferation and migration [11, 21-24]. The regulatory effects of GDNF on glioma progression involve a complex network with multi-molecule coordination. However, it is still unclear how GDNF achieves multi-molecular regulation through limited receptors to promote glioma cell proliferation and migration.

MicroRNAs (miRNAs) are a class of endogenous genes that encode $\sim 22$ nucleotidelong, non-coding, single-stranded RNA molecules that participate in crucial biological processes by imperfectly pairing with target messenger RNAs (mRNAs) of protein-coding genes and transcriptionally or post-transcriptionally regulating their expression $[25,26]$. miRNAs can achieve one-to-many or many-to-one patterns to regulate gene expression [27]. Recent studies have shown abnormal miRNA expression in malignant glioma [28, 29], and these miRNAs can be useful biomarkers [30]. Moreover, some are involved in signaling pathways activated by GDNF, such as c-Jun $\mathrm{N}$ terminal kinase (JNK), extracellular signalregulated kinase 1/2 (ERK-1/2), and p38 MAPK signaling pathways, to promote malignant glioma metastasis and invasive growth [31-34]. Therefore, we hypothesized that high GDNF expression promotes glioma cell proliferation and migration by modulating the expression of specific miRNAs.

We treated human U251 glioma cells with different concentrations of exogenous GDNF for variable times to identify the optimal conditions to promote glioma cell proliferation and migration. miRNA expression levels were measured with microarrays, and the molecular mechanisms of miRNA-mediated, GDNF-promoting glioma cell proliferation and migration were investigated with bioinformatics analysis to predict the functions of differentially expressed miRNAs.

\section{Materials and Methods}

Cell culture

Human U251 glioma cells were cultured in Dulbecco's modified Eagle's medium (DMEM, Gibco/ Invitrogen, Carlsbad, CA, USA) containing 10\% fetal calf serum (Gibco/Invitrogen), supplemented with 100 $\mathrm{U} / \mathrm{mL}$ penicillin and $100 \mathrm{U} / \mathrm{mL}$ streptomycin in a $37^{\circ} \mathrm{C}, 5 \% \mathrm{CO}_{2}$ humidified incubator. 


\section{Cellular Physiology Cell Physiol Biochem 2017;44:1923-1938 \begin{tabular}{l|l|l} 
and Biochemistry & Dublished onlIne: December 08, 2017 & $\begin{array}{l}\text { (c) } 2017 \text { The Author(s). Published by S. Karger AG, Basel } \\
\text { www.karger.com/cpb }\end{array}$
\end{tabular}}

\section{Cell proliferation assay}

U251 glioma cells were inoculated into 96-well plates at a concentration of $8 \times 10^{3}$ cells/well. When cells reached $50 \%$ confluence, the culture medium was changed to serum-free DMEM containing $0.5 \%$ bovine serum albumin (BSA; Sigma-Aldrich, St. Louis, MO, USA) for incubation for $12 \mathrm{~h}$ under the same conditions. Then, the culture medium was replaced with fresh serum-free DMEM containing recombination human GDNF (final concentration of $0,10,50$, or $100 \mathrm{ng} / \mathrm{mL}$; Gibco/Invitrogen) for an incubation period of $12,24,36$, or $48 \mathrm{~h}$. The same volumes of phosphate-buffered saline (PBS) were added into control wells. Proliferation was measured using a cell counting kit-8 (Dojindo Molecular Technologies, Kumamoto, Japan) according to the manufacturer's protocol. The absorbance at $450 \mathrm{~nm}$ was measured using a microplate reader (Biotek Instruments, Winooski, VT, USA).

U251 glioma cells were seeded in each well of 48-well plate at a concentration of $1.2 \times 10^{4}$ cells/well. When cells reached $70 \%$ confluence, the culture medium was changed to serum-free DMEM containing $0.5 \%$ BSA (Sigma-Aldrich), and the cells were cultured for $12 \mathrm{~h}$ under the same conditions. Then the culture medium was replaced with fresh serum-free DMEM containing GDNF (final concentrations of 0 , 10,50 or $100 \mathrm{ng} / \mathrm{mL}$, including $10 \mu \mathrm{M}$ 5-ethynyl-2'-deoxyuridine [EdU]). After $24 \mathrm{~h}$, cells were fixed with $4 \%$ paraformaldehyde for EdU staining, and incubated in $0.5 \%$ Triton X-100 in PBS for 10 min at room temperature. Then the cells were incubated in $1 \times$ Apollo® staining reaction liquid for $30 \mathrm{~min}$ at room temperature in the dark, and nuclei were stained with 4', 6-diamidino-2-phenylindole (DAPI, SigmaAldrich). The cells were then examined and photographed with a fluorescence microscope. Red and blue cells were stained with Apollo ${ }^{\circledR}$ and DAPI, respectively.

\section{Cell cycle assay}

U251 glioma cells were cultured in 60-mm-diameter dishes at a density of (5-8) $\times 10^{5}$ cells per dish. When cells reached $70 \%$ confluence, the culture medium was changed to serum-free DMEM containing $0.5 \%$ BSA (Sigma-Aldrich), and cultured for $12 \mathrm{~h}$ under identical conditions. Then the culture medium was replaced with fresh serum-free DMEM containing GDNF (final concentration of $0,10,50$, or $100 \mathrm{ng} / \mathrm{mL}$ ). After treatment, U251 glioma cells were digested using $0.25 \%$ pancreatic enzyme, washed twice with PBS, fixed in precooled $70 \%(\mathrm{v} / \mathrm{v})$ ethanol overnight, and stained with $100 \mu \mathrm{g} / \mathrm{mL}$ propidium iodide (PI, SigmaAldrich) at $4^{\circ} \mathrm{C}$ for $30 \mathrm{~min}$. DNA content was monitored with a flow cytometer (FACScan; Becton Dickinson, Franklin Lakes, NJ, USA). Flow cytometry data were analyzed using ModFit LT $^{\mathrm{TM}}$ software (Verity Software House, Topsham, ME).

\section{Cell migration and invasion assays}

U251 glioma cells were inoculated into 12 -well plates. When cells reached $100 \%$ confluence, scratch wounds were created with a 10- $\mu \mathrm{L}$ pipette tip. The medium was replaced with fresh serum-free DMEM, and cells were cultured for $12 \mathrm{~h}$ to ensure that wound healing was due to enhanced migration rather than increased cell proliferation. The culture medium was replaced with fresh serum-free DMEM containing GDNF (final concentration of 0,10, 50, or $100 \mathrm{ng} / \mathrm{mL}$ ). Micrographs were taken $0,12,24$ or $36 \mathrm{~h}$ after injury. Wound width was measured with Image-Pro Plus 6.0 software (Media Cybernetics, Rockville, MD, USA).

In vitro invasion assays were performed using Costar Transwell inserts (8-mm pore size; Corning, Corning NY,) in 24-well plates. Before performing invasion assays, cells were cultured for $12 \mathrm{~h}$ with serumfree DMEM. Approximately $1.3 \times 10^{4}$ cells in $100 \mu \mathrm{L}$ of serum-free medium were placed in the upper chamber, and $600 \mu \mathrm{L}$ of the same GDNF-containing medium (final concentration of $0,10,50$, or $100 \mathrm{ng} / \mathrm{mL}$, including $2 \% \mathrm{FBS}$ ) was placed in the lower chamber. The plates were incubated for $36 \mathrm{~h}$ at $37^{\circ} \mathrm{C}$ in $5 \% \mathrm{CO}_{2}$, then the cells were fixed in $4 \%$ paraformaldehyde for $30 \mathrm{~min}$ and stained with $1 \%$ crystal violet for $20 \mathrm{~min}$. Cells on the upper sides of the filters were removed with cotton-tipped swabs, and the filters were washed with PBS. Cells on the undersides of the filters were examined and counted under a microscope.

\section{Microarray analysis}

Total RNAs were extracted using TRIzol reagent (Invitrogen) according to the manufacturer's description and quantified using the NanoDrop ND-1000 (Thermo Fisher Scientific, Waltham, MA, USA). RNA integrity was assessed using standard denaturing agarose gel electrophoresis, purified with the mirVana miRNA Isolation kit (Thermo Fisher Scientific), tailed with polyadenylation polymerase, ligated with biotinylated DNA dendrimers, and hybridized to Affymetrix GeneChip miRNA arrays using the FlashTag ${ }^{\mathrm{TM}}$ Biotin RNA Labeling kit (Genisphere, Hatfield, PA, USA) according to the manufacturer's instructions. Slides 
were scanned with the Affymetrix GeneChip Scanner 3000 (Affymetrix, Santa Clara, CA, USA), and miRNA data were analyzed using the miRNA QC Tool (Affymetrix). A Human LncRNA/mRNA Microarray (Arraystar, Rockville, MD, USA) was used to analyze mRNA expression after GDNF treatment.

\section{Real-time polymerase chain reaction (PCR)}

Total RNAs were purified using TRIzol reagent (Invitrogen) and reverse transcribed using a reverse transcription system (Promega, Madison, WI, USA) according to the manufacturer's description. Real-time PCR was performed using FastStart Universal SYBR Green Master (Roche Diagnostics, Basel, Switzerland) and analyzed with LightCycler ${ }^{\circledR} 480$ real-time fluorescence quantitative PCR (Roche). The miRNA and mRNA primer pairs used are shown in Table 1. Reaction conditions: 95 ${ }^{\circ} \mathrm{C}$, initial denaturation, $30 \mathrm{~s} ; 95^{\circ} \mathrm{C}$, denaturation, $20 \mathrm{~s} ; 60^{\circ} \mathrm{C}$, anneal, $15 \mathrm{~s}$; $72^{\circ} \mathrm{C}$, elongation, $20 \mathrm{~s}$; amplification, 40 cycles. Relative expression levels were calculated as $2^{-\Delta \Delta \mathrm{CT}}$ [35]. The miRNA and target gene mRNA levels were normalized to the housekeeping gene $\beta$-actin.

\section{Cluster analysis}

Unsupervised hierarchical clustering was carried out with average linkage and uncentered correlation as the similarity metrics using Cluster 3.0 software [36]. Heatmaps were generated in Java Treeview. Data from each raw probe from the microarrays of all samples were averaged, and then the respective data from the samples were transformed as the provider divided by the average (mean). Relative expression of each miRNA was calculated as the ratio between the sample microarrays and the average of all microarrays [37]. For figure generation, the relative expression of each gene was described as the $\log _{10}$ (ratio) in the heatmap figures from Cluster 3.0.

\section{Selection of differentially expressed miRNAs and functional analysis}

Differentially expressed miRNAs were identified using the significance analysis of microarrays (SAM) program. The miRNAs with a q-value $\leq 0.05$ and fold change $\geq 2$ or $\leq 0.5$ were considered significantly differentially expressed. Using mirWalk, we predicted the target genes and then selected those targeted by two or more significantly differentially expressed miRNAs to perform Gene Ontology (GO) and Kyoto Encyclopedia of Genes and Genomes (KEGG) pathway analyses. The - $\log _{10}$ (P-values) indicating the GO and pathway results were used in the histogram generated with SigmaPlot (Systat Software, Inc., San Jose, CA, USA).

\section{Neutralization studies}

Native or heat-denatured $\left(5 \mathrm{~min}\right.$ at $100^{\circ} \mathrm{C}$ ) anti-GDNF (Abcam, Cambridge, UK) antibody were separately added to complete DMEM. The medium was incubated with the antibody for 15 min at room temperature before it was added to U251 glioma cells to neutralize GDNF. 
Statistical analysis

All data were analyzed with SPSS 16.0 (SPSS, Chicago, IL, USA) and are expressed as mean \pm standard deviation (SD). Independent sample t-tests were performed to identify significant differences in the mean values between the two groups. One-way analysis of variance (ANOVA) was used to compare the mean values of multiple samples. $P<0.05$ was considered statistically significant.

\section{Results}

GDNF significantly enhanced U251 glioma cell proliferation

CCK8 assays were performed to measure U251 glioma cell activity after treatment with different concentrations of GDNF for variable times. After $24 \mathrm{~h}$, GDNF significantly promoted glioma cell activity $(P<0.05)$ in a dose-dependent manner (Fig. $1 \mathrm{~A}$, Table 2$)$. EdU staining revealed that 50 and $100 \mathrm{ng} / \mathrm{mL}$ GDNF significantly augmented glioma cell proliferation after $24 \mathrm{~h}$ treatment $(P<0.01)$, but there was no significant difference between the two concentrations $(P>0.05)$ (Fig. 1B, C). Cell cycle detection showed that 24-treatment with 50 and $100 \mathrm{ng} / \mathrm{mL}$ GDNF significantly increased the percentage of cells in $\mathrm{S}$ stage $(P<0.05)$, while the proportion of G1 phase cells declined $(P<0.05)$. Again, the difference between the two groups was not significant $(P>0.05$, Fig. 1D).

\section{GDNF significantly increased U251 glioma cell migration and invasion}

Migration was measured with scratch tests after 12, 24, or $36 \mathrm{~h}$ treatment with different concentrations of GDNF. U251 glioma cell migration was significantly enhanced after $24 \mathrm{~h}$ incubation with 50 or $100 \mathrm{ng} / \mathrm{mL}$ GDNF (Fig. 2A, C; Table 3). Transwell experiments were performed to investigate U251 glioma cell invasiveness. The results showed that 24-h treatment with 50 or $100 \mathrm{ng} / \mathrm{mL}$ GDNF significantly promoted the invasion in a dosedependent fashion $(P<0.01)$, and the difference between the two groups was significant $(P$ $<0.05$ ) (Fig. 2B, D).

$\begin{array}{lll}\text { miRNA expression } & \text { Table 2. Effect of GDNF on cell viability of U251 glioma cells. Values } \\ \text { analysis in U251 } & \text { are means } \pm \text { SD of six independent experiments. Significant differences } \\ \text { glioma cells after } & \text { among the groups are indicated by different lowercase letters }(P<0.05) \text {. } \\ \text { GDNF stimulation } & \text { Differences among the groups are indicated by different uppercase let- } \\ \text { To examine how } & \text { ters }(P<0.01)\end{array}$
GDNF induces glioma cells proliferation and migration, we investigated the global miRNA expression of U251 glioma cells incubated with GDNF (50 ng/mL) or PBS (control group) for $24 \mathrm{~h}$ (Fig. 3A). The R package

\begin{tabular}{lcccc}
\hline \multirow{2}{*}{ Group } & \multicolumn{4}{c}{ OD 450} \\
& $12 \mathrm{~h}$ & $24 \mathrm{~h}$ & $36 \mathrm{~h}$ & $48 \mathrm{~h}$ \\
\hline GDNF-0 & $0.99 \pm 0.10^{\mathrm{a}}$ & $1.12 \pm 0.01^{\mathrm{a}}$ & $1.42 \pm 0.05^{\mathrm{a}}$ & $1.44 \pm 0.12^{\mathrm{a}}$ \\
GDNF-10 & $0.99 \pm 0.05^{\mathrm{a}}$ & $1.24 \pm 0.03^{\mathrm{b}}$ & $1.56 \pm 0.09 \mathrm{~b}$ & $1.90 \pm 0.06^{\mathrm{B}}$ \\
GDNF-50 & $0.99 \pm 0.06^{\mathrm{a}}$ & $1.25 \pm 0.04^{\mathrm{b}}$ & $1.64 \pm 0.08^{\mathrm{C}}$ & $2.05 \pm 0.06^{\mathrm{c}}$ \\
GDNF-100 & $0.98 \pm 0.06^{\mathrm{a}}$ & $1.26 \pm 0.02^{\mathrm{b}}$ & $1.63 \pm 0.07 \mathrm{C}$ & $2.10 \pm 0.06^{\mathrm{C}}$ \\
\hline
\end{tabular}

Table 3. Effect of GDNF on cell migration rate of U251 glioma cells. Values are means \pm SD of five independent experiments. Significant differences among the groups are indicated by different lowercase letters $(P<$ 0.05). Differences among the groups are indicated by different uppercase letters $(P<0.01)$.

\begin{tabular}{lcccc}
\hline \multirow{2}{*}{ Group } & \multicolumn{4}{c}{ Migrate rate $(\%)$} \\
& $0 \mathrm{~h}$ & $12 \mathrm{~h}$ & $24 \mathrm{~h}$ & $36 \mathrm{~h}$ \\
\hline GDNF-0 & $102.59 \pm 4.70^{\mathrm{a}}$ & $112.08 \pm 6.40^{\mathrm{a}}$ & $118.77 \pm 8.06^{\mathrm{a}}$ & $125.20 \pm 2.30^{\mathrm{a}}$ \\
GDNF-10 & $100.00 \pm 5.27 \mathrm{a}$ & $115.52 \pm 5.94^{\mathrm{a}}$ & $120.62 \pm 5.94^{\mathrm{a}}$ & $125.06 \pm 6.84^{\mathrm{a}}$ \\
GDNF-50 & $100.00 \pm 3.48^{\mathrm{a}}$ & $131.60 \pm 5.07^{\mathrm{B}}$ & $134.34 \pm 2.16^{\mathrm{B}}$ & $145.51 \pm 10.78^{\mathrm{B}}$ \\
GDNF-100 & $100.00 \pm 5.40^{\mathrm{a}}$ & $139.95 \pm 8.14^{\mathrm{B}}$ & $141.61 \pm 3.23^{\mathrm{Bc}}$ & $153.97 \pm 7.79^{\mathrm{C}}$ \\
\hline
\end{tabular}


Fig. 1. Effect of GDNF $(0,10,50$ and $100 \mathrm{ng} / \mathrm{mL}$ ) on U251 cell proliferation. (A) Viability of U251 glioma cells measured with CCK8 assays. (B, C) EdU analysis about the effects of different concentrations of GDNF on U251 glioma cells proliferation. The cells were labeled with EdU at $10 \mu \mathrm{M}$ for $24 \mathrm{~h}$ and stained with azideconjugated Apollo® (red fluorescence) and DAPI (blue fluorescence). The scale is $100 \mu \mathrm{m}$. Percentage of EdU positive cells $=$ number of red nuclei vs. number of blue nuclei. (D) Cell cycle of U251 glioma cells measured with FCM after treatment of different concentration of GDNF. * $P<0.05,{ }^{* *} P<0.01$.

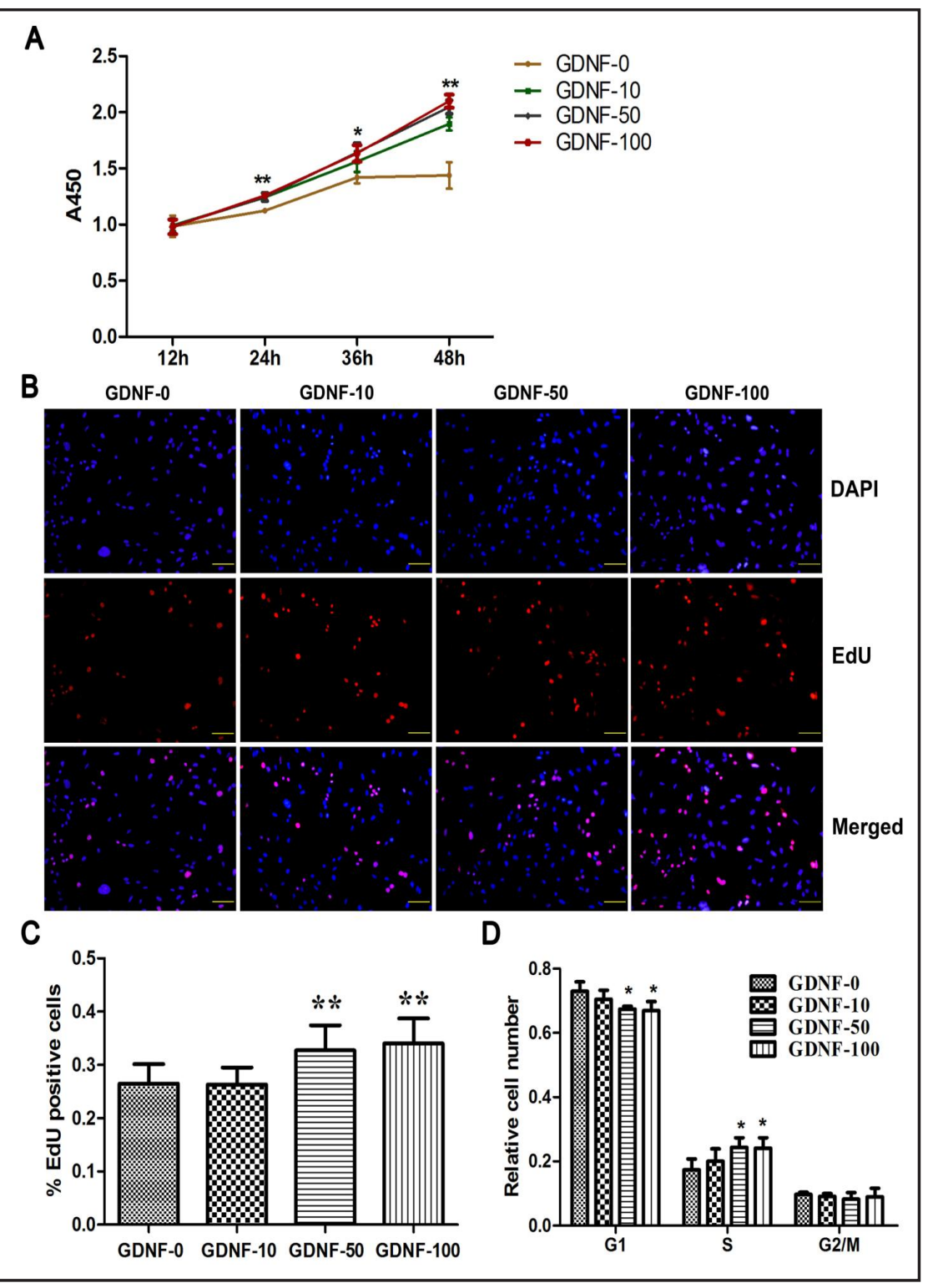

from SAM was used to screen the differential expression of miRNAs using the following criteria: $q$-value $\leq 0.05$ and fold change $\geq 2$ or $\leq 0.5$. A total of seven miRNAs (hsa-miR-1945p, hsa-miR-152-3p, hsa-miR-205-5p, hsa-miR-629-5p, hsa-miR-3609, hsa-miR-183-5p, hsamiR-487b-3p) were differentially expressed, and all seven were up-regulated in response to GDNF stimulation (Table 4). This is clearly illustrated with a log-log scatter plot (Fig. 3B). To verify array data reliability, we randomly selected seven miRNAs (five up-regulated and 2 no change miRNAs) and confirmed their expression in GDNF-treated U251 glioma cells using real-time PCR (Fig. 3C, D). Two up-regulated miRNAs were randomly selected for real-time PCR to confirm their expression levels in GDNF-treated U87 glioma cells (Fig. 3E).

To further clarify the effect of GDNF on miRNA expression, we used an anti-GDNF antibody to neutralize GDNF secreted by U251 glioma cells and performed real-time PCR to measure the expression of hsa-miR-194-5p and hsa-miR-205-5p. The expression levels of these two miRNAs were significantly decreased after neutralizing GDNF $(P<0.05)$ (Fig. 3F). 
Fig. 2. Effect of GDNF $(0,10$, 50 or $100 \mathrm{ng} / \mathrm{mL}$ ) on U251 cell migration and invasion. $(\mathrm{A}, \mathrm{C})$ GDNF promoted wound healing. Quantification of all experiments is shown as: migration rate $=[1-(\mathrm{n}$ h average width of the scratch - $0 \mathrm{~h}$ average width of the scratch) / $0 \mathrm{~h}$ average width of the scratch] $\times 100 \%$. $(B, D)$ GDNF increased the invasion capability of U251 glioma cells. Number of invaded cells were counted in 7 microscopic fields after treatment with various concentrations of GDNF for $24 \mathrm{~h}$. The scale is 100 $\mu \mathrm{m}$. Bar with different uppercase letters is significantly different $(\mathrm{P}<0.01)$. ${ }^{* *} P<0.01$.

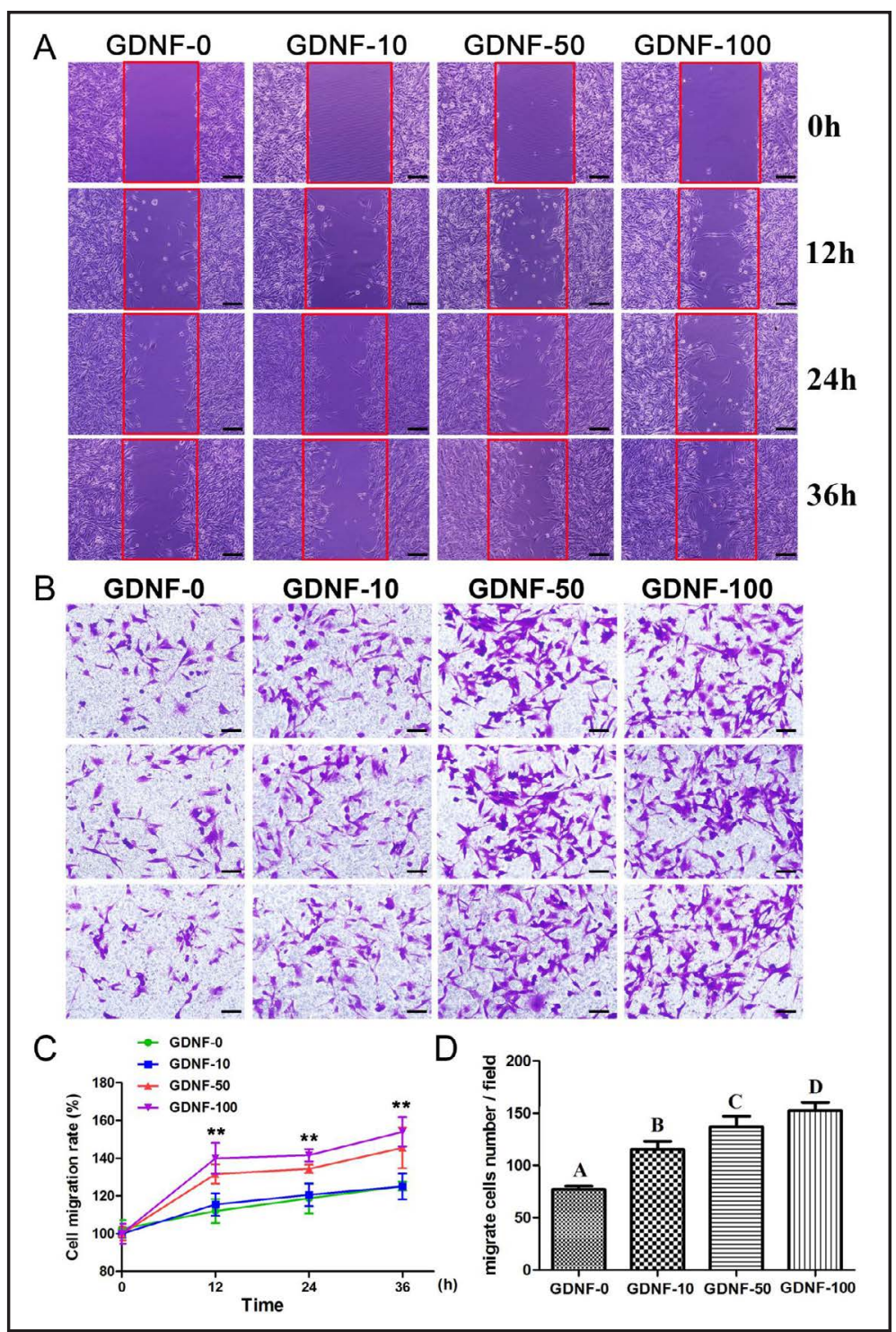

Target prediction and function analysis of co-regulated miRNAs

The target genes of these seven up-regulated miRNAs were predicted with miRWalk (http://www.umm.uni-heidelberg.de/apps/zmf/mirwalk/), which integrates the predictive information of 12 miRNA target prediction databases. If a gene is predicted as target gene by more than 6 databases, these predictions are considered accurate. Next, we selected genes predicted as targets of two or more miRNAs to perform GO and KEGG pathway analyses. The most significant biological processes were G0:0006355 DNA-dependent regulation of transcription, G0:0006350 transcription, GO:0007165 signal transduction, G0:0007275 development, GO:0007155 cell adhesion, and GO:0007049 cell cycle (Fig. 4A). Similarly, pathway analysis showed that the predicted target genes related to these seven up-regulated miRNAs were involved in axon guidance, MAPK signaling, focal adhesion, Wnt signaling, prostate cancer, and glioma (Fig. 4B). Ingenuity pathway analysis (IPA) was performed to generate the regulation network of the seven up-regulated miRNAs with relevant mRNAs and regulating factors. Interestingly, the network indicated that hsa-miR-194-5p, hsamiR-152-3p, hsa-miR-205-5p, hsa-miR-183-5p, and hsa-miR-487b-3p co-regulated tumor protein p53 (TP53) and Akt, which play important roles in glioma development (Fig. 5).

To further evaluate the target prediction results, mRNA levels of TP53, Akt3, serine/ threonine-protein kinase (SIK1) and desmocollin-2 (DSC2) co-targeted by two or more 


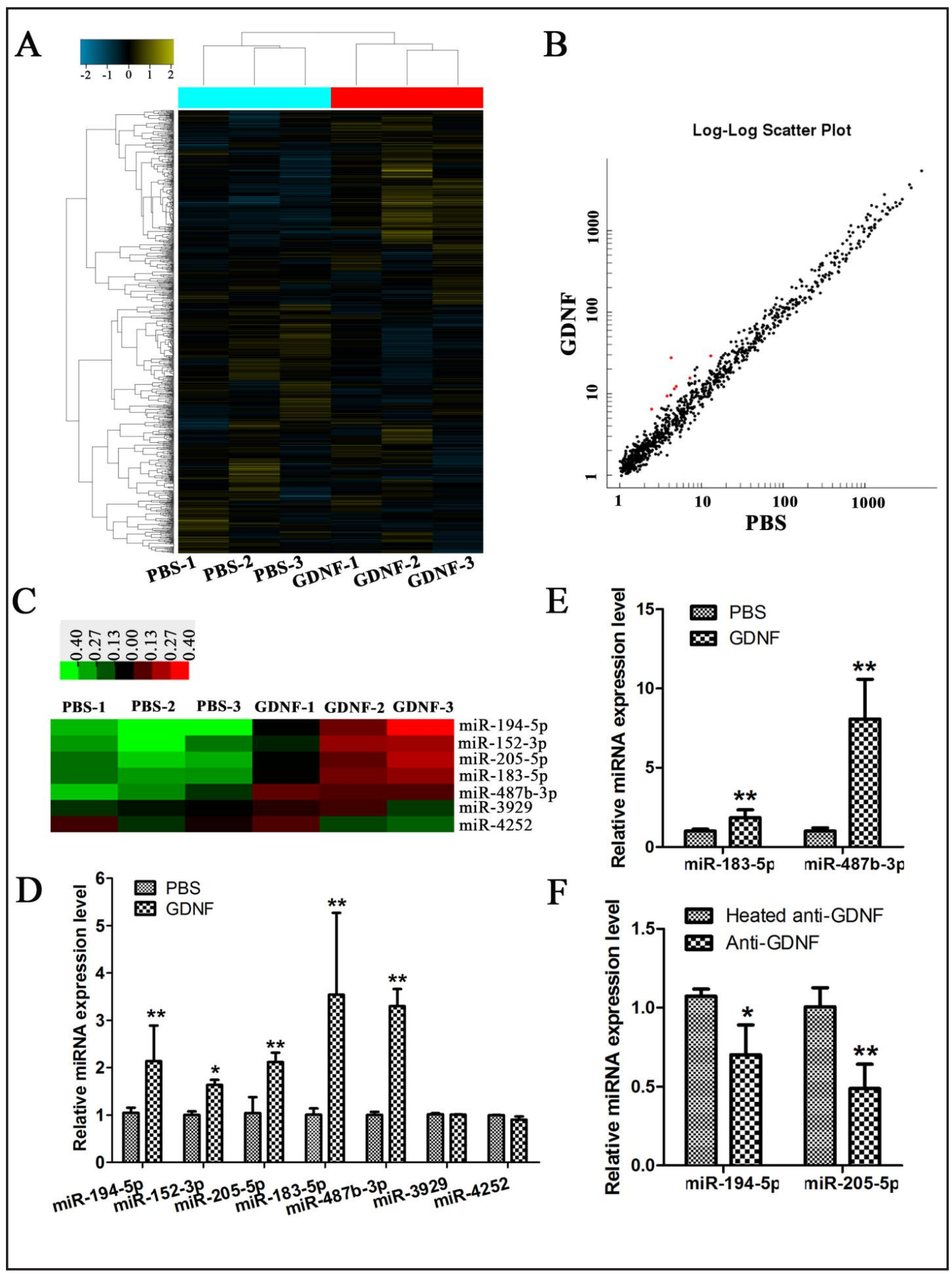

Fig. 3. The expression profiles of global miRNAs in glioma cells stimulated by GDNF ( $50 \mathrm{ng} / \mathrm{ml}$ ) or PBS (control group). (A) Heatmap of global miRNAs in U251 glioma cells after stimulation by GDNF or PBS. (B) Loglog scatter plot comparing global miRNA expression profiles between GDNF and PBS group. (C) Heatmap of selected miRNAs in U251 glioma cells after stimulation by GDNF or PBS. (D) Expression pattern of selected miRNAs in U251 glioma cells tested by real-time PCR. (E) Expression pattern of randomly selected miRNAs in U87 glioma cells tested by real-time PCR. (F) Expression pattern of randomly selected miRNAs in U251 glioma cells neutralizing by GDNF antibody. ${ }^{*} P<0.05,{ }^{* *} P<0.01$. 


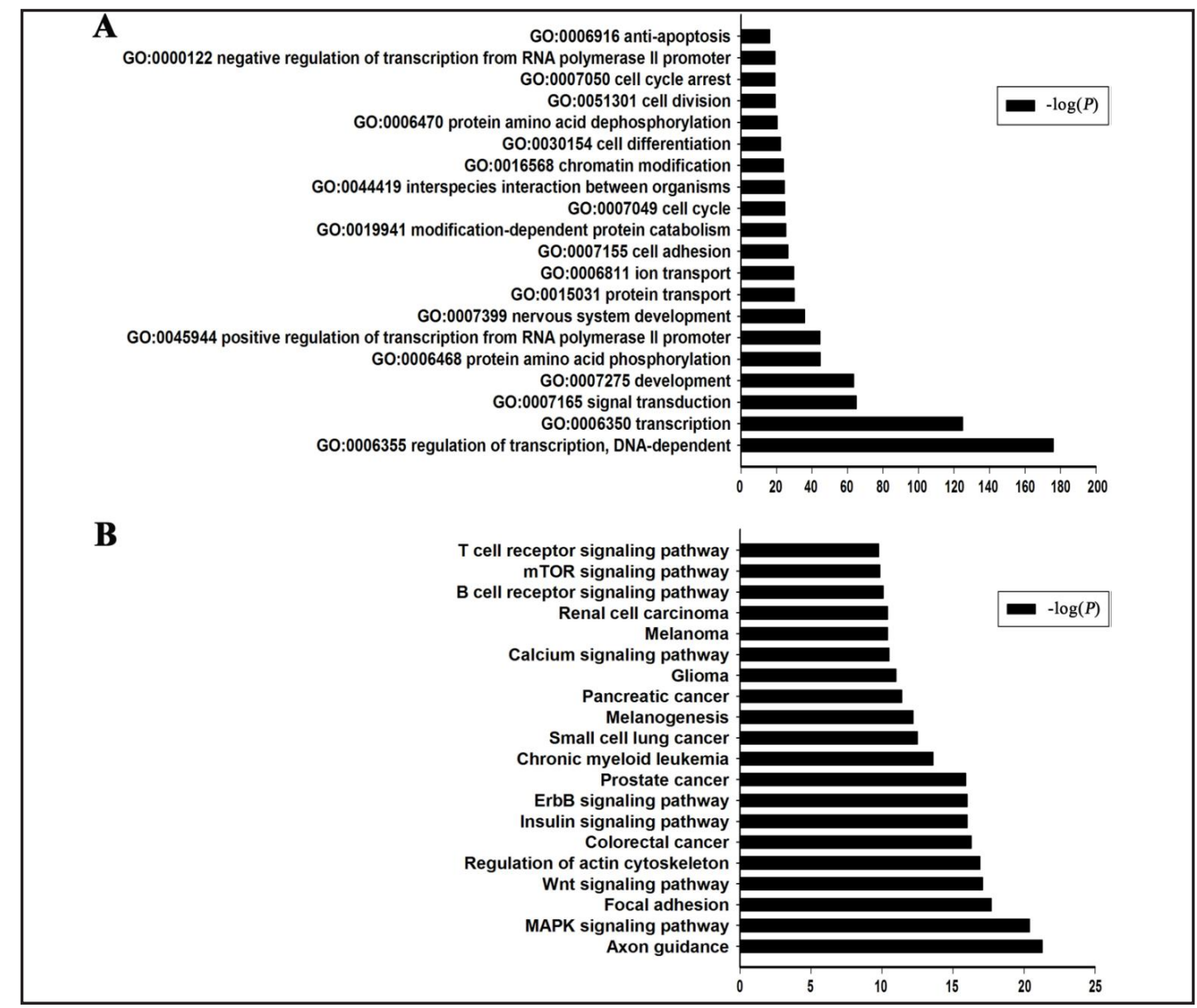

Fig. 4. Functional analysis of the target genes predicted by differentially expressed miRNAs. (A) Major biological processes stimulated by genes targeted by two or more miRNAs from hsa-miR-183-5p, hsa-miR205-5p, hsa-miR-152-3p, hsa-miR-194-5p, hsa-miR-629-5p, hsa-miR-3609 and hsa-miR-487b-3p. (B) Major pathways stimulated by genes targeted by two or more miRNAs from hsa-miR-183-5p, hsa-miR-205-5p, hsa-miR-152-3p, hsa-miR-194-5p, hsa-miR-629-5p, hsa-miR-3609 and hsa-miR-487b-3p.

miRNAs were measured with real-time PCR or mRNA microarray. The mRNA levels of TP53, Akt3, DSC2, and SIK1 in glioma cells were significantly decreased after GDNF treatment $(P<0.05)$ (Fig. 6).

\section{Discussion}

Our results confirmed the
Table 4. Differentially expressed miRNAs in U251 glioma cells after the stimulation of GDNF. q-value $\leq 5$

\begin{tabular}{lcccc}
\hline miRNA & Fold-changed & Style & q-value & Score(d) \\
\hline hsa-miR-194-5p & 6.47 & up & 4.05 & 3.14 \\
hsa-miR-152-3p & 2.63 & up & 4.05 & 2.63 \\
hsa-miR-205-5p & 2.50 & up & 4.05 & 2.82 \\
hsa-miR-629-5p & 2.49 & up & 4.05 & 2.56 \\
hsa-miR-3609 & 2.46 & up & 4.05 & 2.63 \\
hsa-miR-183-5p & 2.24 & up & 4.05 & 2.94 \\
hsa-miR-487b-3p & 2.15 & up & 4.05 & 2.99 \\
\hline
\end{tabular}

findings in previous studies showing that high GDNF expression promotes malignant glioma cell proliferation and migration $[11,14,15,21]$. However, the molecular mechanisms underlying these observations remain unclear. Recent reports indicate miRNAs as an important factor, and the abnormal expression of some miRNAs are involved in GDNF-mediated signaling pathways [31-34]. We tested the hypothesis that GDNF promotes glioma cell proliferation and migration by modulating the expression of specific miRNAs. 
Fig. 5. $\mathrm{Re}-$ sults of IPA analysis of the target genes predicted by differentially expressed miRNAs. Network showing the relationships among the 5 up-regulated miRNAs (hsamiR-194-5p, hsa-miR-1523p, hsa-miR205-5p, hsamiR-183-5p and hsa-miR487b-3p) obtained using IPA.

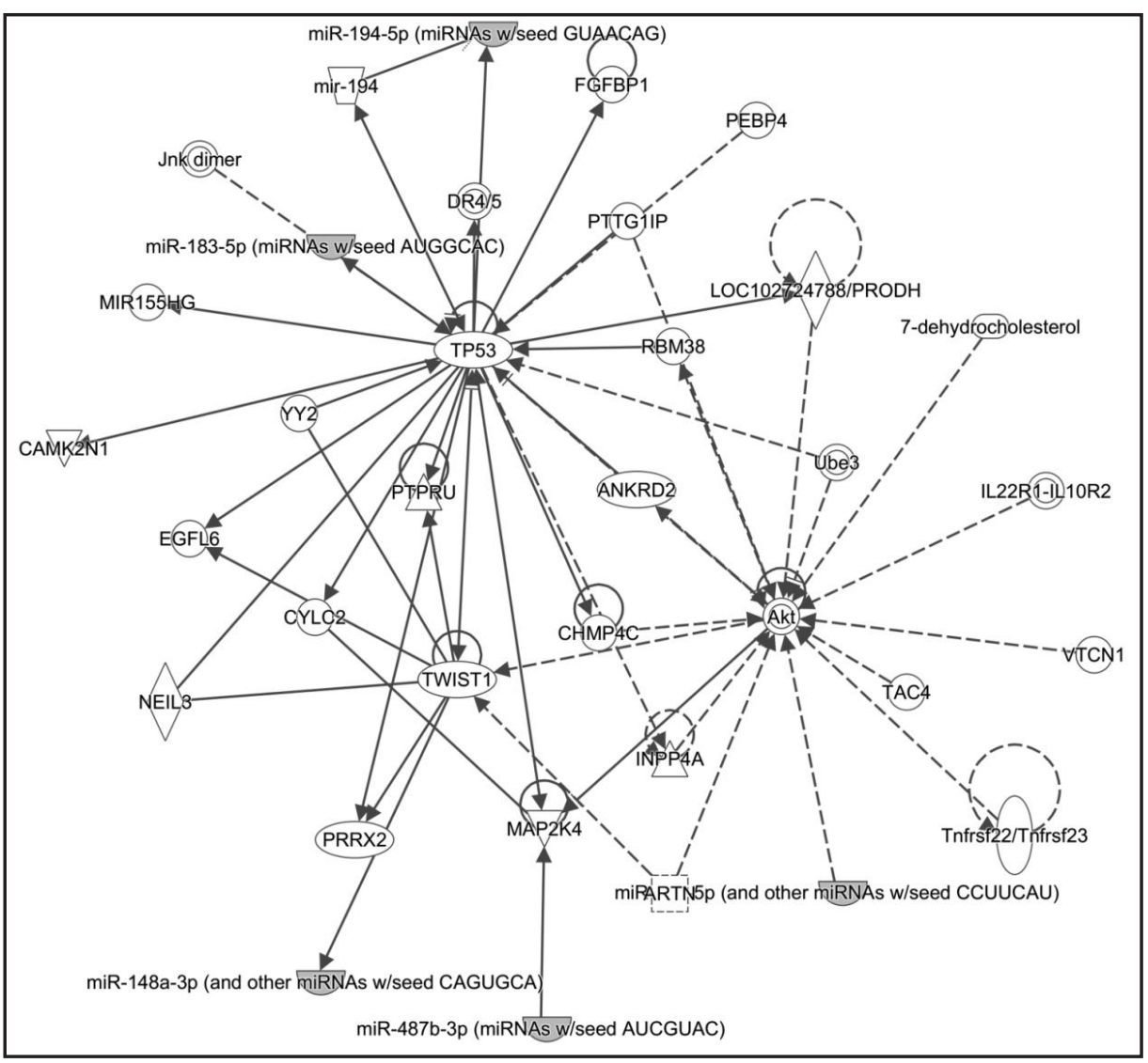

Fig. 6. The mRNA expression levels of target genes predicted by two or more up-regulated miRNAs. (A, B) Expression pattern of TP53 and Akt3 in U251 glioma cells tested by real-time PCR after $24 \mathrm{~h}$ incubation with 50 ng/mL GDNF. (C, D) mRNA microarray data showed that SIK1 and DSC2 were down-regulated in U251 glioma cells after $24 \mathrm{~h}$ incubation with $100 \mathrm{ng} / \mathrm{mL}$ GDNF. (E, F) Expression level of TP53 and SIK1 in U87 glioma cells tested by realtime PCR after $24 \mathrm{~h}$ treatment with $50 \mathrm{ng} / \mathrm{mL}$ GDNF. * $P<0.05$, ** $P<0.01$.

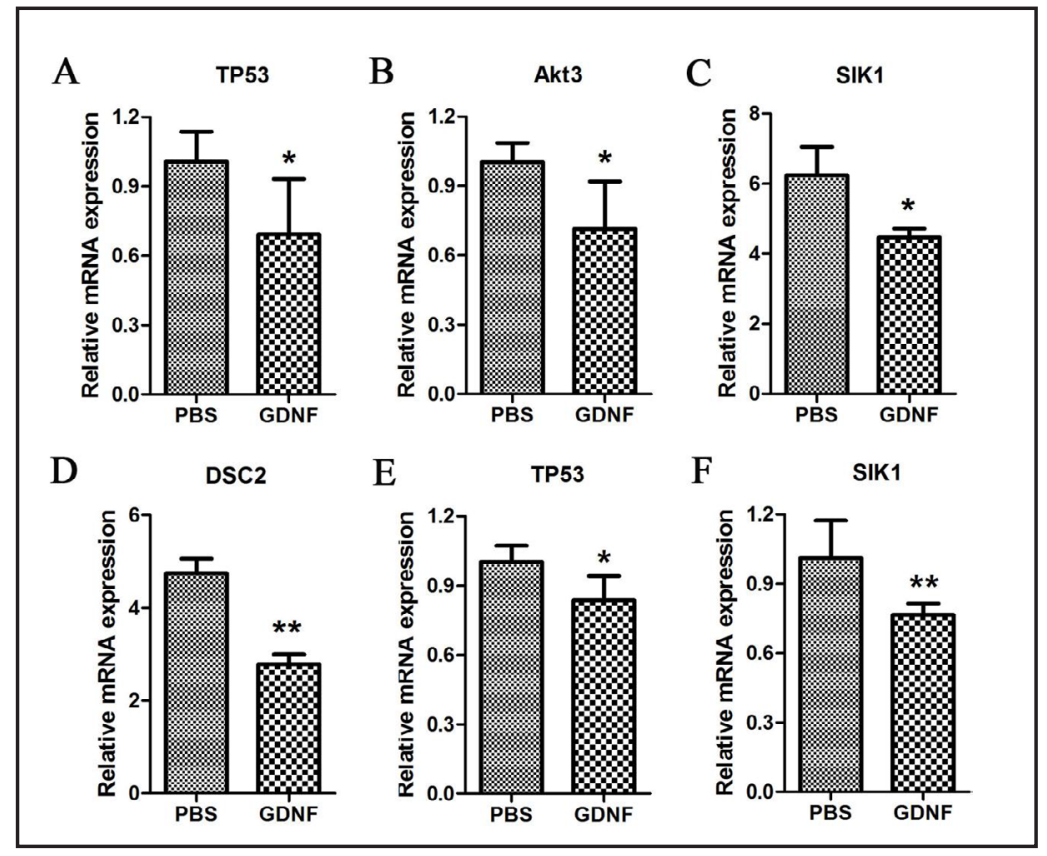

GDNF significantly increased the expression of seven miRNAs in U251 glioma cells, and this observation was confirmed by real-time PCR and neutralization studies in glioma cells (Fig. 3). We next searched 1324 genes that were predicted to be targets of 2 or more of these 7 up-regulated miRNAs. The GO analysis identified target genes involved in transcription 
regulation, signal transduction, cell adhesion, cell cycle, cell differentiation, and anti-apoptosis, all functions closely related to glioma development [38]. Recent studies have reported that precursor $\mathrm{N}$-cadherin and integrin $\beta 1$ proteins serve as signal transduction molecules in GDNF-induced glioma migration [13, 39]. These cell adhesion molecules are associated with 5 miRNAs, namely hsa-miR-183-5p, hsa-miR-205-5p, hsa-miR-152-3p, hsa-miR-629-5p, and hsa-miR-3609. GDNF may regulate adhesion molecule expression via specific miRNAs to affect signaling cascades in glioma cells. DSC2, a desmosomal cadherin protein, is targeted by hsa-miR-205-5p, hsa-miR-152-3p, and hsa-miR-194-5p, and it was down-regulated in U251 glioma cells treated with GDNF (Fig. 6D). Reduced DSC2 expression is significantly correlated with higher tumor grading and is a prognostic biomarker for decreased survival in patients with multiple high-grade carcinomas [40-42]. In addition, we confirmed that GDNF promotes U251 glioma cell proliferation and significantly increases the proportion of cells in the $S$ phase (Fig. 1D). Phosphorylated cyclin-dependent kinase inhibitor 1B (CDKN1B) can inhibit the conversion from the G1 to $S$ phase [43], and it is targeted by hsa-miR-152-3p and hsa-miR-194-5p. U2AF homology motif kinase 1 (UHMK1) is a target gene of hsa-miR-1835p, hsa-miR-205-5p, and hsa-miR-152-3p and can control CDKN1B phosphorylation [44]. Oncostatin M (OSM) targeted by hsa-miR-3609 has been characterized as a potent tumor cell growth inhibitor that induces cell cycle arrest in the G1 phase by increasing p21 1 cip1/Waf1/ sdi1 and p27 $7^{\mathrm{Kip} 1}$ expression in glioma cells [45]. OSMR is one of the heterodimeric receptors for OSM [46], and it is a target gene of hsa-miR-183-5p, hsa-miR-152-3p, and hsa-miR-487b3p. Furthermore, transcription factor 7-like 2 (TCF7L2) targeted by hsa-miR-183-5p, hsamiR-194-5p and hsa-miR-629-5p and cullin-3 (CUL3) targeted by hsa-miR-152-3p and hsamiR-194-5p also regulate G1 arrest [47, 48]. Collectively, our findings suggest that miRNAs influence GDNF-induced glioma cell proliferation via their effects on cell cycle regulatory factors.

KEGG pathways were queries to identify the specific signal pathways including the seven up-regulated miRNA target genes. The results revealed that participate in colorectal cancer, prostate cancer, pancreatic cancer, glioma, and other cancer-related pathways. Among these, MAPK, Wnt, and mammalian target of rapamycin (mTOR) signaling pathways are closely related to glioma occurrence and development [49]. These signaling cascades primarily down-regulate tumor-suppressor genes and up-regulate tumor-causing genes in glioma [11, 15, 50-52]. Taking tuberous sclerosis complex-1 (TSC1) as an example, it acts as a tumor suppressor in complex with TSC2 to influence cell adhesion, migration, and fate determination in the central nervous system [53]. Deregulation of TSC expression is implicated in $\sim 50 \%$ of deaths among children diagnosed with a brain tumor [53]. Moreover, Tsc1 deficiency upregulates mTOR complex 1 activity and accelerates malignant gliomagenesis [54]. mTOR inhibitors have recently been used to treat astrocytomas in patients with TSC [55-57]. Here we revealed that hsa-miR-183, a contributor of glioma progression [58], can work with hsamiR-3609 to target Tsc1 gene expressions. SIK1 is another tumor inhibitor that plays a key role in p53/TP53-dependent anoikis and can suppress metastasis [59]. SIK1 is targeted by hsa-miR-152-3p and hsa-miR-629-5p, and our previous mRNA microarray data showed that SIK1 was down-regulated in U251 glioma cells after 24-h incubation with $100 \mathrm{ng} / \mathrm{mL}$ GDNF (Fig. 6C). Previous studies have demonstrated that GDNF can promote glioma cell growth by activating MAPK signaling $[11,50,60]$, which is consistent with our findings. We found that hsa-miR-152-3p, hsa-miR-194-5p, hsa-miR-629-5p, and hsa-miR-3609b all are able to target MAPK, and hsa-miR-152-3p and hsa-miR-194-5p are both concerned with glioma development $[61,62]$. In addition, MAP2K, MAP3K, and ATF2, the key factors in the MAPK signaling pathway, are also target genes of hsa-miR-629-5p, hsa-miR-3609, and hsa-miR183-5p.

The comprehensive functions of the seven differentially expressed miRNAs were evaluated after constructing the regulatory network of differentially expressed miRNAs with mRNAs and other regulatory factors using IPA analysis. TP53 and Akt were at the core of the regulatory network, and they are related to five (hsa-miR-194-5p, hsa-miR-152-3p, hsa-miR205-5p, hsa-miR-183-5p, and hsa-miR-487b-3p) of the seven miRNAs. These two genes are involved in tumorigenesis, cell cycling, and cell survival, underscoring the importance of these 


\section{Cellular Physiology Cell Physiol Biochem 2017;44:1923-1938 \begin{tabular}{l|l} 
and Biochemistry $10.1159 / 000485883$ & $\begin{array}{l}\text { O 2017 The Author(s). Published by S. Karger AG, Basel } \\
\text { www.karger.com/cpb }\end{array}$
\end{tabular} \\ Zhang et al.: miRNAs Regulate GDNF-Promoting Glioma Progression}

miRNAs in glioma occurrence and development. TP53 is an important tumor suppressorgene, and loss of its function can significantly promote glioma formation and development [63-65]. A recent study found that hsa-miR-183-5p is involved in pituitary tumor aggressiveness and malignancy via regulation of P53 expression [66]. Its levels were notably higher in glioma tissue compared to normal brain tissue and were significantly positive correlated with tumor size and World Health Organization grade [67]. Our results further demonstrate that GDNF can significantly increase hsa-miR-183-5p expression in glioma cells. Diaz-Rodriguez et al. reported that GDNF and p53 levels were negatively correlated in somatotropinomas [68], which is consistent with our findings in U251 and U87 glioma cells (Fig. 6A, E). High GDNF levels may inhibit P53 expression by up-regulating hsa-miR-183-5p to promote glioma development. In addition, bioinformatics analysis revealed that up-regulated hsamiR-152-3p targets TP53 and another tumor suppressor, phosphatase and tensin homolog deleted on chromosome ten (PTEN) [69, 70]; it is also involved in glioma cell invasion and angiogenesis via neuropilin 2 (NRP-2) and MMP-3 [71]. Tumor protein p53-inducible nuclear protein 1 (TP53INP1) and apoptosis-stimulating of p53 protein 2 (TP53BP2) are the target genes of hsa-miR-205-5p and participate in the regulation of P53 activity [72, 73]. TP53INP1 regulates p53-dependent apoptosis through phosphorylation at Ser46, serving as a co-factor for the putative p53-Ser46 kinase [72]. TP53BP2 can enhance the DNA binding and trans-activation of TP53 on the promoters of pro-apoptotic genes [73]. Moreover, hsamiR-205-5p holds potential as a prognostic indicator for glioma, especially for patients with advanced disease [74]. Akt, also known as PKB or Rac, includes three transcripts (Akt1, Akt2, and Akt3) that play important roles in cell survival and apoptosis. Akt3 is the target gene of hsa-miR-629-5p and hsa-miR-205-5p, and its mRNA expression decreased after GDNF treatment (Fig. 6B). Recent studies have shown that Akt3 can significantly inhibit the glioma cell aggressiveness and slow down disease progression [75]. Akt3 is mainly expressed in the brain and is crucial for malignant glioma cell viability [76], which may be the key molecule in MMP13 regulation via IL13 [77].

\section{Conclusion}

We confirmed that glioma cell proliferation and migration are significantly promoted by GDNF, and miRNAs regulate these processes. All significantly differentially expressed miRNAs are involved in cell adhesion and division function, which are closely related to glioma progression. Five significantly highly expressed miRNAs influenced levels of TP53 and Akt, which are involved in tumorigenesis, cell cycling, and cell survival and play an important role in glioma occurrence and development. This suggests that these five miRNAs, especially miR-183, could be useful biological markers for glioma detection. Expression levels of TP53, Akt3, SIK1 and DSC2 co-targeted by two or more up-regulated miRNAs were decreased in GDNF-treated glioma cells. However, these predictions are merely a starting point for studying differentially expressed miRNAs induced by GDNF in glioma cells; the exact functions of these miRNAs remain to be clarified.

\section{Acknowledgements}

This project was supported by the National Natural Science Foundation of China (Grant number: 81602464, 81372698, 81402918 and 81300553), Natural Science Foundation of Jiangsu (BK20130212, BK20140228), China and Jiangsu Postdoctoral Science Foundation funded project (2013M540466 and 1301068C), Qing Lan Project (2017 to Bao-Le Zhang), Jiangsu Overseas Research \& Training Program for University Prominent Yong \& Middleaged Teachers and Presidents (2016 to Bao-Le Zhang) and A Project Funded by the Priority Academic Program Development of Jiangsu Higher Education Institutions (PAPD). 


\section{Cellular Physiology Cell Physiol Biochem 2017;44:1923-1938 \begin{tabular}{l|l} 
and Biochemistry Published onlne'Pecember 08, 2017 & $\begin{array}{l}\text { (c) } 2017 \text { The Author(s). Published by S. Karger AG, Basel } \\
\text { www.karger.com/cpb }\end{array}$
\end{tabular}}

Zhang et al.: miRNAs Regulate GDNF-Promoting Glioma Progression

\section{Disclosure Statement}

The authors disclose no potential conflicts of interest.

\section{References}

1 Poon CC, Sarkar S, Yong VW, Kelly JJP: Glioblastoma-associated microglia and macrophages: targets for therapies to improve prognosis. Brain 2017;140:1548-1560.

2 Errico A: CNS cancer: new options for glioblastoma. Nat Rev Clin Oncol 2014;11:124.

- 3 Ng WH, Wan GQ Peng ZN, Too HP: Glial cell-line derived neurotrophic factor (GDNF) family of ligands confer chemoresistance in a ligand-specific fashion in malignant gliomas. J Clin Neurosci 2009;16:427-436.

4 Edwards LA, Woolard K, Son MJ, Li A, Lee J, Ene C, Mantey SA, Maric D, Song H, Belova G: Effect of brain-and tumor-derived connective tissue growth factor on glioma invasion. J Natl Cancer I 2011;103:1162-1178.

-5 Hamerlik P, Lathia JD, Rasmussen R, Wu Q, Bartkova J, Lee M, Moudry P, Bartek J, Fischer W, Lukas J: Autocrine VEGF-VEGFR2-Neuropilin-1 signaling promotes glioma stem-like cell viability and tumor growth. J Exp Med 2012;209:507-520.

6 Lin LF, Doherty DH, Lile JD, Bektesh S, Collins F: GDNF: a glial cell line-derived neurotrophic factor for midbrain dopaminergic neurons. Science 1993;260:1130-1132.

7 Yu ZQ Zhang BL, Ni HB, Liu ZH, Wang JC, Ren QX, Mo JB, Xiong Y, Yao RQ, Gao DS: Hyperacetylation of histone H3K9 involved in the promotion of abnormally high transcription of the gdnf gene in glioma cells. Mol Neurobiol 2014;50:914-922.

-8 Trupp M, Raynoschek C, Belluardo N, Ibanez CF: Multiple GPI-anchored receptors control GDNF-dependent and independent activation of the c-Ret receptor tyrosine kinase. Mol Cell Neurosci 1998;11:47-63.

-9 Shen Q Yin Y, Xia QJ, Lin N, Wang YC, Liu J, Wang HP, Lim A, Wang TH: Bone Marrow Stromal Cells Promote Neuronal Restoration in Rats with Traumatic Brain Injury: Involvement of GDNF Regulating BAD and BAX Signaling. Cell Physiol Biochem 2016;38:748-762.

10 Wiesenhofer B, Stockhammer G, Kostron H, Maier H, Hinterhuber H, Humpel C: Glial cell line-derived neurotrophic factor (GDNF) and its receptor (GFR-alpha 1) are strongly expressed in human gliomas. Acta Neuropathol 2000;99:131-137.

11 Song H, Moon A: Glial cell-derived neurotrophic factor (GDNF) promotes low-grade Hs683 glioma cell migration through JNK, ERK-1/2 and p38 MAPK signaling pathways. Neurosci Res 2006;56:29-38.

12 Ng WH, Wan GQ Peng ZN, Too HP: Glial cell-line derived neurotrophic factor (GDNF) family of ligands confer chemoresistance in a ligand-specific fashion in malignant gliomas. J Clin Neurosci 2009;16:427-436.

13 Xiong Y, Liu L, Zhu S, Zhang B, Qin Y, Yao R, Zhou H, Gao DS: Precursor N-cadherin mediates glial cell linederived neurotrophic factor-promoted human malignant glioma. Oncotarget 2017;8:24902-24914.

14 Ku MC, Wolf SA, Respondek D, Matyash V, Pohlmann A, Waiczies S, Waiczies H, Niendorf T, Synowitz M, Glass R, Kettenmann H: GDNF mediates glioblastoma-induced microglia attraction but not astrogliosis. Acta Neuropathol 2013;125:609-620.

15 Shabtay-Orbach A, Amit M, Binenbaum Y, Na'ara S, Gil Z: Paracrine regulation of glioma cells invasion by astrocytes is mediated by glial-derived neurotrophic factor. Int J Cancer 2015;137:1012-1020.

-16 Durbec P, Marcos-Gutierrez CV, Kilkenny C, Grigoriou M, Wartiowaara K, Suvanto P, Smith D, Ponder B, Costantini F, Saarma M, Sariola H, Pachnis V: GDNF signalling through the Ret receptor tyrosine kinase. Nature 1996;381:789-793.

17 Cao JP, Yu JK, Li C, Sun Y, Yuan HH, Wang HJ, Gao DS: Integrin beta1 is involved in the signaling of glial cell line-derived neurotrophic factor. J Comp Neurol 2008;509:203-210.

-18 Zuo T, Qin JY, Chen J, Shi Z, Liu M, Gao X, Gao D: Involvement of N-cadherin in the protective effect of glial cell line-derived neurotrophic factor on dopaminergic neuron damage. Int J Mol Med 2013;31:561-568.

19 Li L, Cao J, Zhang S, Wang C, Wang J, Song G, Wang H, Zhang L: NCAM signaling mediates the effects of GDNF on chronic morphine-induced neuroadaptations. J Mol Neurosci 2014;53:580-589.

20 Li L, Chen H, Wang M, Chen F, Gao J, Sun S, Li Y, Gao D: NCAM-140 Translocation into Lipid Rafts Mediates the Neuroprotective Effects of GDNF. Mol Neurobiol 2017;54:2739-2751.

21 Lu DY, Leung YM, Cheung CW, Chen YR, Wong KL: Glial cell line-derived neurotrophic factor induces cell migration and matrix metalloproteinase-13 expression in glioma cells. Biochem Pharmacol 2010;80:12011209. 


\section{Cellular Physiology Cell Physiol Biochem 2017;44:1923-1938

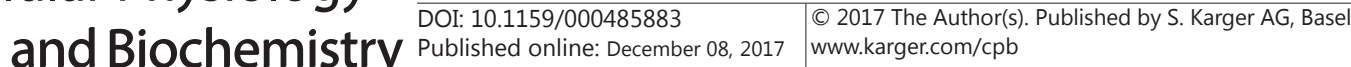

Zhang et al.: miRNAs Regulate GDNF-Promoting Glioma Progression

22 Shabtay-Orbach A, Amit M, Binenbaum Y, Na'ara S, Gil Z: Paracrine regulation of glioma cells invasion by astrocytes is mediated by glial-derived neurotrophic factor. Int J Cancer 2014;10.1002/ijc.29380

-23 Qu DW, Liu Y, Wang L, Xiong Y, Zhang CL, Gao DS: Glial cell line-derived neurotrophic factor promotes proliferation of neuroglioma cells by up-regulation of cyclins PCNA and Ki-67. Eur Rev Med Pharmacol Sci 2015;19:2070-2075.

24 Wan G, Too HP: A specific isoform of glial cell line-derived neurotrophic factor family receptor alpha 1 regulates RhoA expression and glioma cell migration. J Neurochem 2010;115:759-770.

25 Bartel DP, Chen CZ: Micromanagers of gene expression: the potentially widespread influence of metazoan microRNAs. Nat Rev Genet 2004;5:396-400.

26 Rajewsky N: microRNA target predictions in animals. Nat Genet 2006;38 Suppl:S8-13.

27 Laffont B, Rayner KJ: MicroRNAs in the Pathobiology and Therapy of Atherosclerosis. Can J Cardiol 2017;33:313-324.

28 Conti A, Romeo SG, Cama A, La Torre D, Barresi V, Pezzino G, Tomasello C, Cardali S, Angileri FF, Polito F, Ferlazzo G, Di Giorgio R, Germano A, Aguennouz M: MiRNA expression profiling in human gliomas: upregulated miR-363 increases cell survival and proliferation. Tumour Biol 2016;37:14035-14048.

29 Zhang C, Li C, Li J, Han J, Shang D, Zhang Y, Zhang W, Yao Q Han L, Xu Y, Yan W, Bao Z, You G, Jiang T, Kang C, Li X: Identification of miRNA-mediated core gene module for glioma patient prediction by integrating highthroughput miRNA, mRNA expression and pathway structure. PLoS One 2014;9:e96908.

-30 Barciszewska AM: MicroRNAs as efficient biomarkers in high-grade gliomas. Folia Neuropathol 2016;54:369-374.

31 Chen XH, Ling XM, Shi S: microRNA-106a induces the proliferation and apoptosis of glioma cells through regulating JNK/MAPK pathway. Eur Rev Med Pharmacol Sci 2015;19:3412-3417.

-32 Jones TA, Jeyapalan JN, Forshew T, Tatevossian RG, Lawson AR, Patel SN, Doctor GT, Mumin MA, Picker SR, Phipps KP, Michalski A, Jacques TS, Sheer D: Molecular analysis of pediatric brain tumors identifies microRNAs in pilocytic astrocytomas that target the MAPK and NF-kappaB pathways. Acta Neuropathol Commun 2015;3:86.

-33 Li Y, Ge P, Ma C: MiR-126 Regulates the ERK Pathway via Targeting KRAS to Inhibit the Glioma Cell Proliferation and Invasion. Mol Neurobiol 2017;54:137-145.

-34 Liu Z, Jiang Z, Huang J, Huang S, Li Y, Yu S, Liu X: miR-7 inhibits glioblastoma growth by simultaneously interfering with the PI3K/ATK and Raf/MEK/ERK pathways. Int J Oncol 2014;44:1571-1580.

-35 Livak KJ, Schmittgen TD: Analysis of relative gene expression data using real-time quantitative PCR and the 2(-Delta Delta C(T)) Method. Methods 2001;25:402-408.

36 de Hoon MJ, Imoto S, Nolan J, Miyano S: Open source clustering software. Bioinformatics 2004;20:14531454.

-37 Sun L, Xie H, Mori MA, Alexander R, Yuan B, Hattangadi SM, Liu Q, Kahn CR, Lodish HF: Mir193b-365 is essential for brown fat differentiation. Nat Cell Biol 2011;13:958-965.

-38 Reni M, Mazza E, Zanon S, Gatta G, Vecht CJ: Central nervous system gliomas. Crit Rev Oncol Hematol 2017;113:213-234.

39 Touihri-Barakati I, Kallech-Ziri O, Ayadi W, Kovacic H, Hanchi B, Hosni K, Luis J: Cucurbitacin B purified from Ecballium elaterium (L.) A. Rich from Tunisia inhibits alpha5beta1 integrin-mediated adhesion, migration, proliferation of human glioblastoma cell line and angiogenesis. Eur J Pharmacol 2017;797:153161.

40 Knosel T, Chen Y, Hotovy S, Settmacher U, Altendorf-Hofmann A, Petersen I: Loss of desmocollin 1-3 and homeobox genes PITX1 and CDX2 are associated with tumor progression and survival in colorectal carcinoma. Int J Colorectal Dis 2012;27:1391-1399.

-41 Hamidov Z, Altendorf-Hofmann A, Chen Y, Settmacher U, Petersen I, Knosel T: Reduced expression of desmocollin 2 is an independent prognostic biomarker for shorter patients survival in pancreatic ductal adenocarcinoma. J Clin Pathol 2011;64:990-994.

42 Fang WK, Gu W, Li EM, Wu ZY, Shen ZY, Shen JH, Wu JY, Pan F, Lv Z, Xu XE, Huang Q Xu LY: Reduced membranous and ectopic cytoplasmic expression of DSC2 in esophageal squamous cell carcinoma: an independent prognostic factor. Hum Pathol 2010;41:1456-1465.

-43 Bockstaele L, Kooken H, Libert F, Paternot S, Dumont JE, de Launoit Y, Roger PP, Coulonval K: Regulated activating Thr172 phosphorylation of cyclin-dependent kinase 4(CDK4): its relationship with cyclins and CDK "inhibitors". Mol Cell Biol 2006;26:5070-5085. 


\section{Cellular Physiology Cell Physiol Biochem 2017;44:1923-1938 \begin{tabular}{l|l} 
and Biochemistry POI: 10.1159/000485883 & $\begin{array}{l}\text { (c) } 2017 \text { The Author(s). Published by S. Karger AG, Basel } \\
\text { www.karger.com/cpb }\end{array}$
\end{tabular}

44 Nakamura S, Okinaka K, Hirano I, Ono T, Sugimoto Y, Shigeno K, Fujisawa S, Shinjo K, Ohnishi K: KIS induces proliferation and the cell cycle progression through the phosphorylation of p27Kip1 in leukemia cells. Leuk Res 2008;32:1358-1365.

-45 Halfter H, Friedrich M, Resch A, Kullmann M, Stogbauer F, Ringelstein EB, Hengst L: Oncostatin M induces growth arrest by inhibition of Skp2, Cks1, and cyclin A expression and induced p21 expression. Cancer Res 2006;66:6530-6539.

-46 Mosley B, De Imus C, Friend D, Boiani N, Thoma B, Park LS, Cosman D: Dual oncostatin M (OSM) receptors. Cloning and characterization of an alternative signaling subunit conferring OSM-specific receptor activation. J Biol Chem 1996;271:32635-32643.

47 Yu Y, Wu J, Wang Y, Zhao T, Ma B, Liu Y, Fang W, Zhu WG, Zhang H: Kindlin 2 forms a transcriptional complex with beta-catenin and TCF4 to enhance Wnt signalling. EMBO Rep 2012;13:750-758.

48 Sumara I, Quadroni M, Frei C, Olma MH, Sumara G, Ricci R, Peter M: A Cul3-based E3 ligase removes Aurora B from mitotic chromosomes, regulating mitotic progression and completion of cytokinesis in human cells. Dev Cell 2007;12:887-900.

-49 Rajesh Y, Pal I, Banik P, Chakraborty S, Borkar SA, Dey G, Mukherjee A, Mandal M: Insights into molecular therapy of glioma: current challenges and next generation blueprint. Acta Pharmacol Sin 2017;10.1038/ aps.2016.167

50 Oh-hashi K, Kaneyama M, Hirata Y, Kiuchi K: ER calcium discharge stimulates GDNF gene expression through MAPK-dependent and -independent pathways in rat C6 glioblastoma cells. Neurosci Lett 2006; 405:100-105.

51 Bao Z, Xu X, Liu Y, Chao H, Lin C, Li Z, You Y, Liu N, Ji J: CBX7 negatively regulates migration and invasion in glioma via Wnt/beta-catenin pathway inactivation. Oncotarget 2017;10.18632/oncotarget.16587

-52 Miyata H, Ashizawa T, Iizuka A, Kondou R, Nonomura C, Sugino T, Urakami K, Asai A, Hayashi N, Mitsuya K, Nakasu Y, Yamaguchi K, Akiyama Y: Combination of a STAT3 Inhibitor and an mTOR Inhibitor Against a Temozolomide-resistant Glioblastoma Cell Line. Cancer Genomi Proteom 2017;14:83-91.

53 Berhouma M: Management of subependymal giant cell tumors in tuberous sclerosis complex: the neurosurgeon's perspective. World J Pediatr 2010;6:103-110.

54 Yamada D, Hoshii T, Tanaka S, Hegazy AM, Kobayashi M, Tadokoro Y, Ohta K, Ueno M, Ali MA, Hirao A: Loss of Tsc1 accelerates malignant gliomagenesis when combined with oncogenic signals. J Biochem 2014;155:227-233.

-55 Komotar RJ, Starke RM, Connolly ES, Sisti MB: mTOR inhibitors in the treatment of subependymal giant-cell astrocytomas associated with tuberous sclerosis. Neurosurgery 2011;68:N24-25.

56 Major P: Potential of mTOR inhibitors for the treatment of subependymal giant cell astrocytomas in tuberous sclerosis complex. Aging (Albany NY) 2011;3:189-191.

57 Jancic J, Duric V, Ivancevic N, Nikolic B, van den Anker JN, Samardzic J: Current Use of mTOR Inhibitors for the Treatment of Subependymal Giant Cell Astrocytomas and Epilepsy in Patients with TSC. Curr Med Chem 2016;23:4260-4269.

58 Pavlakis E, Tonchev AB, Kaprelyan A, Enchev Y, Stoykova A: Interaction between transcription factors PAX6/PAX6-5a and specific members of miR-183-96-182 cluster, may contribute to glioma progression in glioblastoma cell lines. Oncol Rep 2017;37:1579-1592.

-59 Cheng H, Liu P, Wang ZC, Zou L, Santiago S, Garbitt V, Gjoerup OV, Iglehart JD, Miron A, Richardson AL, Hahn WC, Zhao JJ: SIK1 couples LKB1 to p53-dependent anoikis and suppresses metastasis. Sci Signal 2009;2:ra35.

60 Di Benedetto B, Kuhn R, Nothdurfter C, Rein T, Wurst W, Rupprecht R: N-desalkylquetiapine activates ERK1/2 to induce GDNF release in C6 glioma cells: a putative cellular mechanism for quetiapine as antidepressant. Neuropharmacology 2012;62:209-216.

-61 Yao Y, Ma J, Xue Y, Wang P, Li Z, Liu J, Chen L, Xi Z, Teng H, Wang Z, Liu Y: Knockdown of long non-coding RNA XIST exerts tumor-suppressive functions in human glioblastoma stem cells by up-regulating miR-152. Cancer Lett 2015;359:75-86.

62 Zhang X, Wei C, Li J, Liu J, Qu J: MicroRNA-194 represses glioma cell epithelialtomesenchymal transition by targeting Bmi1. Oncol Rep 2017;37:1593-1600.

63 Chen YJ, Hakin-Smith V, Teo M, Xinarianos GE, Jellinek DA, Carroll T, McDowell D, MacFarlane MR, Boet R, Baguley BC, Braithwaite AW, Reddel RR, Royds JA: Association of mutant TP53 with alternative lengthening of telomeres and favorable prognosis in glioma. Cancer Res 2006;66:6473-6476. 


\section{Cellular Physiology Cell Physiol Biochem 2017;44:1923-1938 \begin{tabular}{l|l|l} 
DOI: 10.1159/000485883 & O 2017 The Author(s). Published by S. Karger AG, Basel \\
www.karger.com/cpb
\end{tabular} \\ Zhang et al.: miRNAs Regulate GDNF-Promoting Glioma Progression}

64 Wang X, Chen JX, Liu JP, You C, Liu YH, Mao Q: Gain of function of mutant TP53 in glioblastoma: prognosis and response to temozolomide. Ann Surg Oncol 2014;21:1337-1344.

65 Wang X, Chen JX, Liu YH, You C, Mao Q: Mutant TP53 enhances the resistance of glioblastoma cells to temozolomide by up-regulating O(6)-methylguanine DNA-methyltransferase. Neurol Sci 2013;34:14211428.

-66 Roche M, Wierinckx A, Croze S, Rey C, Legras-Lachuer C, Morel AP, Fusco A, Raverot G, Trouillas J, Lachuer J: Deregulation of miR-183 and KIAA0101 in Aggressive and Malignant Pituitary Tumors. Front Med (Lausanne) 2015;2:54.

67 Ye Z, Zhang Z, Wu L, Liu C, Chen Q, Liu J, Wang X, Zhuang Z, Li W, Xu S, Hang C: Upregulation of miR-183 expression and its clinical significance in human brain glioma. Neurol Sci 2016;37:1341-1347.

-68 Diaz-Rodriguez E, Garcia-Rendueles AR, Ibanez-Costa A, Gutierrez-Pascual E, Garcia-Lavandeira M, Leal A, Japon MA, Soto A, Venegas E, Tinahones FJ, Garcia-Arnes JA, Benito P, Angeles Galvez M, Jimenez-Reina L, Bernabeu I, Dieguez C, Luque RM, Castano JP, Alvarez CV: Somatotropinomas, but not nonfunctioning pituitary adenomas, maintain a functional apoptotic RET/Pit1/ARF/p53 pathway that is blocked by excess GDNF. Endocrinology 2014;155:4329-4340.

69 Zhang Z, Li Y, Sheng C, Yang C, Chen L, Sun J: Tanshinone IIA inhibits apoptosis in the myocardium by inducing microRNA-152-3p expression and thereby downregulating PTEN. Am J Transl Res 2016;8:31243132.

-70 Wang S, Wang L, Dou L, Guo J, Fang W, Li M, Meng X, Man Y, Shen T, Huang X, Li J: MicroRNA 152 regulates hepatic glycogenesis by targeting PTEN. FEBS J 2016;283:1935-1946.

-71 Zheng X, Chopp M, Lu Y, Buller B, Jiang F: MiR-15b and miR-152 reduce glioma cell invasion and angiogenesis via NRP-2 and MMP-3. Cancer Lett 2013;329:146-154.

-72 Okamura S, Arakawa H, Tanaka T, Nakanishi H, Ng CC, Taya Y, Monden M, Nakamura Y: p53DINP1, a p53inducible gene, regulates p53-dependent apoptosis. Mol Cell 2001;8:85-94.

-73 Samuels-Lev Y, O’Connor DJ, Bergamaschi D, Trigiante G, Hsieh JK, Zhong S, Campargue I, Naumovski L, Crook T, Lu X: ASPP proteins specifically stimulate the apoptotic function of p53. Mol Cell 2001;8:781-794.

-74 Hou SX, Ding BJ, Li HZ, Wang L, Xia F, Du F, Liu LJ, Liu YH, Liu XD, Jia JF, Li L, Wu ZL, Zhao G, Zhang ZG, Deng YC: Identification of microRNA-205 as a potential prognostic indicator for human glioma. J Clin Neurosci 2013;20:933-937.

75 Joy A, Kapoor M, Georges J, Butler L, Chang Y, Li C, Crouch A, Smirnov I, Nakada M, Hepler J, Marty M, Feuerstein BG: The role of AKT isoforms in glioblastoma: AKT3 delays tumor progression. J Neurooncol 2016;130:43-52.

76 Paul-Samojedny M, Pudelko A, Kowalczyk M, Fila-Danilow A, Suchanek-Raif R, Borkowska P, Kowalski J: Knockdown of AKT3 and PI3KCA by RNA interference changes the expression of the genes that are related to apoptosis and autophagy in T98G glioblastoma multiforme cells. Pharmacol Rep 2015;67:1115-1123.

77 Moriya C, Jinnin M, Yamane K, Maruo K, Muchemwa FC, Igata T, Makino T, Fukushima S, Ihn H: Expression of matrix metalloproteinase-13 is controlled by IL-13 via PI3K/Akt3 and PKC-delta in normal human dermal fibroblasts. J Invest Dermatol 2011;131:655-661. 